\title{
References:
}

1. Cf. P. W. Schmiedel, Encyclopaedia Biblica, cols. 4775-6.

2. R. Martin Pope, art. 'Gifts', Hastings' Dictionary of the Apostolic Church, vol. I, p. 451.

3. W. James, Varieties of Religious Experience, pp. 23, 478. M. Barnett, The Living Flame, pp. 129f.

4. See H. A. Guy, New Testament Prophecy, p. 144 (and references). And for glossolalia, see P. Volz, Der Geist Gottes, p. 197, quoted by M. Barnett, The Living Flame, p. 103. Both Guy and Barnett offer valuable criticisms of theories postulating the essential similarity of Christian and non-Christian prophecy and glossolalia.

5. Cf. Leslie D. Weatherhead, Psychology, Religion and Healing, pp. $85 \mathrm{ff}$. J. C. Lambert, art. 'Healing, Gifts of', International Standard Bible Encyclopaedia, vol. II, p. 1350a.

6. Guy, op. cit., pp. 150ff., and Barnett, op. cit., pp. 113ff. give various reasons for the decline of prophetism. C. von Otrelli, art. 'Prophecy', I.S.B.E., vol. IV, p. 2464a, claims that prophecy has never ceased altogether.

7. Cf. Conyers, Middleton, Introductory Discourse, pp. xlvi-xlvii. John Tillotson, Sermon Fol. 3 it. Vol. 3, p. 488. Edit. 1735. Nathaniel Marshall, Epistles of Cyprian, not. b. Henry Dodwell, Dissert. in Iren. 2. para. LV. Daniel Waterland, Treatise on the Importance of the Doctrine of the Trinity, pp. 299, 382-3, 425, 497. John Chapman, Miscell. Tracts., p. 170. William Whiston, Account of the Daemoniacs, p. 65. All the above cited in Middleton, Introductory Discourse, pp. xlvii-li ; and in Warfield, Miracles, pp. 7f. Cf. Wesley, Works, Vol. V, p. 706. Cited by Warfield, Miracles, p. 8, who also refers to later supporters of the theory.

8. Middleton, Free Enquiry, p. 9.

9. Warfield, Miracles, 'The Cessation of the Charismata' (pp. 3-31), passim. Cf. F. J. Foakes-Jackson, History of the Christian Church, p. 241, note 1.

10. Warfield, op. cit., pp. 3, $21 \mathrm{f}$.

11. W. H. Griffith Thomas, The Holy Spirit of God, pp. 48-49.

\section{THE KINGDOM, THE POWER AND THE GLORY}

It is generally accepted that the idea of the kingdom of God was the central theme in the preaching of Jesus. Most scholars would also agree with T. W. Manson that it is 'something through and through spiritual' and 'a personal relation between God and the individual human being', while, of course, implying a community of people who would live together under the rule of God. But concerning the time of the coming of the kingdom there still remains considerable disagreement. It seems that there are grave weaknesses in all the main positions that have come to my notice at least. Thorough-going eschatology has lost much ground and is faced with many passages in the Gospels as we have them, which seem to state quite clearly that the kingdom has arrived (whatever may be the meaning of engiken in Mk. i. 15). If that is what Jesus taught, we have to assume that a disappointed Church managed to adjust itself well enough to the situation to read back into the words of Jesus a more correct interpretation than He had been able to offer. In opposition to that is set realized eschatology. We are greatly indebted to Prof. Dodd and others for the important light that they have shed upon the subject in this direction, but there are places in such a work as The Parables of the Kingdom where his exegesis seems to be strained further than is legitimate. There are sayings in all strands of the synoptic tradition which are hard to apply to anything but the Parousia (e.g. Mk. viii. 38 ; Mt. xxiv. 27 ; Lk. xvii. 24 from $Q$; Mt. xix. 28 from $M$; Lk. xxi. 31 from $L$.) There are too many references to be written off as being due to misunderstanding by the early Church. If they were so radically wrong on so vital a matter, the reliability of the 
evangelists must indeed be small. Prof. Fuller says that the kingdom came with the cross and resurrection of Christ, and he, too, though obviously stressing an important truth, appears unable to account satisfactorily for the sayings which seem to assert that the kingdom has actually arrived during the ministry (Mt. xi. 12; Lk. xvi. 16; Mt. xii. 28 ; Lk. xi. 20). Likewise, Prof. Manson's emphasis on Peter's confession as the turningpoint of the ministry, whilst being a valuable insight, seems to stress the human response too much and to minimize the truth that God is acting in history whether men hear or forbear. To us the most helpful work on the subject, from a very limited reading list, is Mr. Stott's Men with a Message. While we do not agree with all his conclusions, Mr. Stott seems undoubtedly correct when he states that the conception of the kingdom is not a static one, but that there is progress both as God gives it and as man receives it.

How then are we to find an over-all scheme which will be able to account for the sayings in the Gospels as they are? It would only seem legitimate to write any off as unauthentic if this has first proved impossible. The first step is to analyse the conception of kingship. In its essence, its constituents are power and glory (moral attributes which belong to the kingdom of God are not relevant here). In the Old Testament both are attributed to the king and especially to Yahweh as King of Israel (e.g. Ps. xxiv. 8). But as there is always the possibility of the rejection of His sovereignty, there enters into it also an element of judgment (e.g. note the stress on judgment in the royal Pss. xciii-xcix). All the sayings in the Gospels concerning the coming of the kingdom and the coming of the Son of man (and we take the two phrases to be descriptions of the same events) seem to be concerned with one or more of these aspects of kingship. Moreover, all the main events of the life of Jesus, incarnate and glorified, seem to have some connection with one or more of these elements. If one element seems particularly prominent it does not of course mean that the other elements are not present also, if in lesser measure.

The kingship of the Babe of Bethlehem is clearly brought out in both Matthaean and Lucan accounts of His birth, and there are clear references to power, glory and judgment in the Lucan narrative of the presentation in the Temple. Then there are three major experiences of Jesus. At His baptism the Holy Spirit descends as a sign of power, in the temptation He is tested and so God's judgment becomes operative, and the transfiguration denotes His glory. These at least are the most prominent associations of these events. The actions of Jesus during His life are called by Mark dunameis as he stresses the power of Christ, while in John they are semeia in which the Son of God manifested His glory (ii. 11). Perhaps the cursing of the fig tree provides the best example of a work of judgment. The entry into Jerusalem was evidently understood by the evangelists as a time when the kingdom came, as is shown by their quotation from Zechariah. There are clear marks of power, glory and judgment in His cleansing of the Temple. In some senses the kingdom reached its culmination in the cross and resurrection, for then Jesus showed that He was prepared to fulfil His mission to the bitter end, and God confirmed it and vindicated Him by raising Him from the dead. Again, the three strands are present and are perhaps best expressed in the fourth Gospel. His death is referred to as an exaltation and glorification which had the power to draw all men to Himself and at which the prince of this world was judged (Jn. xii. 31, 32). But the coming of the kingdom was not then complete. It needed to be manifested in glory at the ascension and exaltation, in power at Pentecost and in judgment at the destruction of Jerusalem. Finally, of course, there was to be the consummation at the Parousia.

It is in the three events of the ascension, Pentecost and the destruction, that a key may well be found for the verses which have caused most difficulty. Mark ix. 1: "There be some of them that stand here, which shall not taste of death, till they have seen the kingdom of God come with power', is usually referred to the Parousia. But if we are correct in seeing an emphasis in the aspect of power rather than of glory and judgment, it may be legitimate to refer it to Pentecost. By then Jesus and Judas at least had tasted death and Peter had promised that he would be willing to, though his courage failed him in the event. Pentecost is associated 
with power much more strongly than the transfiguration, of which the chief significance is the display of the glory of Christ.

Mark xiv. $62:$ "Ye shall see the Son of man sitting on the right hand of power, and coming in the clouds of heaven', is also generally applied to the second coming. But the fact that it is based upon the coronation passages (Ps. cx. 1 and Dn. vii. 13) suggests that it might suitably be referred to the exaltation of Christ. The verb erchomai is not necessarily used in a spatial sense, but, even if it is to be so taken here, it may have the sense of movement from the earth as perhaps in Dn. vii (cf. Heb. xi. 8 where it means 'go' rather than 'come'). It would seem that opsesthe could refer to the signs which followed to show that He had been glorified, though if it is to be pressed literally, it may be that some of the Sanhedrin saw the cloud which 'received him out of their sight' (Acts i. 9).

A third saying, which has proved a thorn in the flesh to all but the thoroughgoing eschatological school, is Matthew $\mathbf{x} .23$ : "Ye shall not have gone over the cities of Israel, till the Son of man be come.' I would suggest that this may refer to the coming of the Son of man in judgment upon the persecutors of the disciples at the destruction of Jerusalem. If it was possible to speak of Cyrus as the servant of the Lord, because he accomplished some of His purposes though he did not know Him, could not the Son of man come through the agency of Titus? The saying then has some point. There would not be time to evangelize the whole of Palestine, or at least they would not have been forced by persecution to go the rounds of all its towns, before the Romans should come to take away the Jewish place and nation.

The problem of Mark xiii has been dealt with by Mr. Stibbs in the T.S.F. Letter of Autumn 1954, in which he distinguishes the two events spoken of, the destruction of Jerusalem which was to happen in that generation, and the Parousia, of which the date was unknown. There is probably much fruitful study to be done on the significance of 'this generation' (a phrase often used in the Gospels). It is simply worth mentioning in passing that the crucifixion is generally dated $\mathrm{AD} 30$ and the destruction in $\mathrm{AD} 70$. That gives us a period of exactly forty years between the exodos (Lk. ix. 31) and the full possession by the Church of the Jewish inheritance. There is clearly much further light which might be shed upon these ideas from Ps. Xcv and Heb. iii-iv. (See also, for emphasis on the significance of the fall of Jerusalem, Lamont, Studies in the Johannine Writings, and Brandon, The Fall of Jerusalem and the Christian Church.)

What shall we then say to these things? We should submit that every verse in the Gospels on the subject of the kingdom is explicable without forcing and that we are to see a progressive coming of the kingdom with the cross-resurrection as the decisive moment and the Parousia as the consummation. But every action of Jesus and every event in His life was associated with His one great purpose of bringing the rule of God amongst men.

Holy Trinity Church, Hull.

R. E. NIXON.

\section{NOTES AND NEWS}

\section{Publications by Members}

S. B. Babbage, Mobs and Men, Exp. Times lxix, pp. 307ff.

J. N. Birdsall, Photius and the Text of the Fourth Gospel, NTS iv, pp. $61 \mathrm{ff}$. The Missing Leaves of Codex 213 of the New Testament, JTS (NS) ix, pp. $78 \mathrm{ff}$.

G. W. Bromiley, The Sacramental Teaching and Practice in the Reformation Churches (Eerdmans).

F. F. Bruce, A Commentary on Ephesians and Colossians (with E. K. Simpson) (Eerdmans).

Colossians : an expanded paraphrase, $E Q \times \mathrm{xxx}$, pp. $45 \mathrm{ff}$.

Romans : an expanded paraphrase - I, $E Q \times \times x \times, p p .98 \mathrm{ff}$.

The Spreading Flame (Paternoster Press).

H. L. Ellison, Ezekiel: The Man and his Message (Paternoster Press).

The Christian Approach to the Jew (Edinburgh House Press). 